\title{
Fanon and the child: pedagogies of subjectification and transformation
}

DOI:

10.1080/03626784.2016.1168263

\section{Document Version}

Accepted author manuscript

Link to publication record in Manchester Research Explorer

\section{Citation for published version (APA):}

Burman, E. (2016). Fanon and the child: pedagogies of subjectification and transformation. Curriculum Inquiry, 46(3), 265-285. https://doi.org/10.1080/03626784.2016.1168263

\section{Published in:}

Curriculum Inquiry

\section{Citing this paper}

Please note that where the full-text provided on Manchester Research Explorer is the Author Accepted Manuscript or Proof version this may differ from the final Published version. If citing, it is advised that you check and use the publisher's definitive version.

\section{General rights}

Copyright and moral rights for the publications made accessible in the Research Explorer are retained by the authors and/or other copyright owners and it is a condition of accessing publications that users recognise and abide by the legal requirements associated with these rights.

\section{Takedown policy}

If you believe that this document breaches copyright please refer to the University of Manchester's Takedown Procedures [http://man.ac.uk/04Y6Bo] or contact uml.scholarlycommunications@manchester.ac.uk providing relevant details, so we can investigate your claim.

\section{OPEN ACCESS}


Fanon and the child: pedagogies of subjectification and transformation

\title{
Erica Burman
}

Manchester Institute of Education, University of Manchester

and

Centre for the Study of Migration and Society, University of Witswatersrand

\section{Accepted (though uncorrected) text of article appearing in Curriculum Inquiry,}

DOI 10.1080/03626784.2016.1168263 (2016)

\begin{abstract}
Frantz Fanon's analysis of colonial experience has widely influenced educational theory and practice. Yet despite much focus on the gendered and sexed dynamics of racialization processes, and their applications to the dynamics in particular of teaching and learning, surprisingly little attention has been given to how these intersect both with generational relations and the models of children/childhood on which his account relies. In this paper, Fanon's representations of childhood across all his texts are analysed and evaluated. It is argued that attending to the diversities and instabilities of these representations not only strengthens critical engagement with Fanon's ideas conceptually, methodologically and in terms of pedagogical process, but also prompts reassessment of their contemporary relevance for, and corresponding challenges to, current pedagogical and political practice.
\end{abstract}

Keywords: child as method; colonialism; racialization; gender; decolonization; educational theory 
2) P a g e 
Models of childhood and education reflect global histories of north- south relations-, both via the positions accorded child-learner and adult-teacher, and the characteristics or attributes with which they are endowed. These histories, and current legacies, continue to reverberate within discourses of national development and so-called 'underdevelopment'. These discourses of development therefore carry moral-political as well as economic meanings attaching not only to notions of 'growing up' but also of 'catching up' (Chen, 2012). As Nandy (1984) pointed out, the model of the child as ignorant and in need of (western) knowledge has long structured the colonial relationship between coloniser and colonized. Notwithstanding this, in policy discourse, education is usually assumed to be a valued 'good', as indicated by the ways education figures in transnational discourse (as in the United Nations Millennium Development Goals of the past decade, which have now been reformulated as Sustainability Goals), and in national government policies on social mobility (as in the UK All Party Parliamentary Group on Social Mobility's claims about links between early intervention and economic development, Allen, 2011a, 2011b). Yet, like notions of economic development, models of individual development in which representations of childhood figure in significant ways -threaten to recapitulate old racialized, classed and gendered pathologizations. Today, critical reconsideration of colonial histories and their legacies becomes more urgent. While models of children, childhoods and educational theory and practice have long been implicated in colonialism, as is now widely acknowledged (Stoler, 2002; Levander 2006; Cannella \& Viruru, 2004), such analyses help make sense of current political conditions and events. For example, the radical Islamic group currently terrorising Nigeria goes under the name Boko Haram, which (imperfectly) translates as 'western education is forbidden'. Not only does this highlight the role of education within colonialism, 
but recent analyses have drawn on Fanon's ideas to indicate why and how education has come to be the site of such contention (Hansen \& Musa, 2013).

Proposing an approach I call 'child as method', this article analyses Frantz Fanon's writings to highlight a set of interconnected themes around childhood, culture, subjectivity and intersubjective relations. While Fanon did not set out to be a theorist of childhood, I suggest the ways he figured and reconfigured 'the child' merits scrutiny both as a key site for evaluating his political and philosophical commitments and as a contribution to the renewed interest in mobilising his insights to inform approaches to childhood and education (Dutro \& Bien, 2014; Gaztambide-Fernández, 2010; Zembylas, 2015). After highlighting key features at play in the reception and interpretation of Fanon's work, including those indicated by his diverse political, intellectual and disciplinary trajectories, I present examples from his account of his own childhood and childhood context, Martinique. I next explore the political agencies addressed to and about children and childhood in his subsequent works (written in the context of the Algerian liberation struggle 1956-62) in relation to the role he accorded education within the project of national development (to which he became passionately committed). I then revisit the iconic encounter staged between Fanon and a (white, male) child that is the primary configuration of childhood, or more properly adult-child relations, associated with his psychoaffective and psychopolitical account of racialization. I interrogate aspects of this encounter that appear to have escaped significant critical inquiry, and these insights are then taken up in relation to a critical reading of the broader range of representations of childhood mobilised (metaphorically, generationally and empirically) in Fanon's writings. Finally, I evaluate 
5 | P a g e

these representations as a resource towards the formulation of counterhegemonic and transformative models of subjectivity, concluding with some reflections on the contemporary geopolitical relevance of these considerations.

\section{Fanon's trajectories}

While Fanon's ideas circulate routinely within teacher education and pedagogical theory in North America and are widely drawn upon outside Europe, in India and Africa for example, they remain little cited within many educational contexts in the global North (including my own, the UK). Hence, I begin by offering a short description of his life and relevance before moving on to address his writing in more detail.

A controversial figure, Fanon is styled in many ways (see e.g. Alessandrini, 1997) - as a revolutionary, cultural or postcolonial theorist and as a political revolutionary. Born in Martinique and living through its transition from colony to 'Département' of France, Fanon experienced firsthand the contradictory conditions of coloniality and postcoloniality, both in his native land and then - having 'earned' his free education fighting for a 'free France' in the Second World War - as a student and newly qualified medical professional in France. His experiences of being rendered alien and estranged within the supposed 'mother country', so passionately discussed in Black Skin, White Masks (hereafter BSWM, Fanon, 1952/1970), are akin to those published around the same time by James Baldwin on Paris, and Ralph Ellison on African-American experience in the US. As biographers and commentators have noted (Macey, 1012; Hudis, 2015), these experiences - observed in relation to others (including the racism 
6 | P a g e

towards North African soldiers he noted during his time in the Free French Army) as well as directed to him personally - prompted his political identification and active engagement with anti-colonial movements, and his move from France's colonial centre (from Paris to Lyon for his studies) to its periphery and frontline zone of conflict and struggle in Algeria. ${ }^{1}$

Fanon's contribution has variously been described as 'social psychoanalysis' (Pinar, 2011), and a 'psychopolitical' (Hook, 2005; 2012) or 'psychoaffective' (Hage, 2010) account of colonial experience. Recent engagements with his work have also been informed by the development of the discipline of 'psychosocial studies', which specifically addresses ways of exploring socialpsyche relations (Frosh and Baraitser, 2008; Burman, 2008; Hook, 2012).These various formulations attempt to characterise Fanon's distinctive attention to the psychic impacts of oppression that permeate the subject at unconscious as well as conscious levels (giving rise to some psychoanalytic inflections) (Burman, in press b). Fanon was thereby showing the intimacy of connection not only between the psychological and the social but also how this socially produced psyche is mediated by and enacted through the body (see also Oliver, 2004). In drawing on these descriptions, like other commentators, I aim to set in play Fanon's attention to emotion or affect as well as the social and political in the constitution of racialized subjectivity. Moreover, as we shall see, Fanon not only mobilises but also subverts the affectivity or emotion that the figure of the child evokes, highlighting the significance - for practitioners working with adults and children (whether as educators, therapists or politicians) - of the sociocultural conditions for the production of those individual affects (Burman, 2016). That is, to formulate the psychoaffective or psychosocial in a way that neither reduces the 
social to the psychological, nor subordinates the individual to the social, but rather attends to the political structuring of the psyche: to subjectification.

Such considerations bring to the fore how, as well as being a theorist of colonial subjectivity and political activist with and for the Algerian Front Libération National (FLN) revolutionary struggle, Fanon was also a psychiatrist. While his psychiatric practice can be read as both traditional and reforming (Macey, 2012), its more radical or revolutionary features owed much to the 'institutional psychotherapy' approach he learnt from the Catalan Marxist émigré François Tosquelles during his internship at Saint Albin, which he put into practice in Algeria when he took up the post of clinical director of a psychiatric hospital. Yet it is largely as a politically-engaged philosopher of subjectivity that his work has been taken up in educational discussions (Leonardo, 2011; De Lissovoy, 2010), albeit one that emphasises its psychoaffective (emotional, sometimes traumatogenic) qualities.

Fanon's work resists disciplinary categorisation, moving as it does between philosophy, literature, politics and psychiatry. This complexity and diversity is also reflected in shifts of political orientation noticeable across his writings. These span a turbulent decade from the 1950s to 1960 s, as well as Fanon's engagement with key inspirational intellectual figures (including Sartre and Merleau Ponty), and direct participation in debates about négritude and pan-African relations. Yet it is worth recalling that Fanon was not a psychoanalyst, a cultural analyst or philosopher by profession. Rather, he drew on a range of resources to inform his psychopolitical account of subjectivity. Overall, Fanon was a socialist as well as theorist of decolonization (with the title of his last book Wretched of the Earth alluding to the 
Internationale), and indeed some have argued that his analyses contribute significantly to Marxist theory (Rabaka, 2011).

Fanon's writing has become iconic for describing the kinds of psychic suffering produced by oppression, alienation and exploitation. As Khanna (2013, p.131) suggests:

What Fanon's work shows is a different sort of relationality that remains particularly insightful for work today. He understands the situation of colonialism to produce a supplementary and disposable population - those in asylums and those seeking asylums - to show us something about a form of supplement as theorized by that other Algerian, Jacques Derrida, as both confinement and excess, and as critique.

In particular, Fanon's work as both a political theorist and psychiatric practitioner addressed the challenge of responding to socially produced distress and revolutionary action, in particular theorising the subjectivity of the colonised, the one who is subjected to racist/colonial oppression. The perpetrators of colonial oppression and its victims, both torturers and the tortured, encountered each other in the space of the asylum he directed at Blida-Joinville, outside Algiers. Indeed after less than three years Fanon resigned his clinical post, on the grounds that it was ethically as well as practically untenable to continue this psychiatric work in the context of the brutal, 'dirty', war being waged by the French.

Interpreting Fanon's writing poses various interpretive challenges that go beyond both its disciplinary ambiguities and Fanon's changing professional and political priorities. These include the different politics attributed to him, especially through the association with the ideas of 
Jean-Paul Sartre, giving rise to significant misconceptions about his understandings of violence (see Hallwood's 2011, and Macey's 2012 discussions of this point), alongside shifts in political position across his different texts. ${ }^{2}$ Moreover, his writing style is passionate, highly rhetorical and richly allusive (involving long extracts - especially in BSWMfrom other writers, especially in BSWM). His text works performatively, invoking the affects he describes so that - as an additional complication for questions of both reception and interpretation - the process of reading recreates the experience he is writing about (Desai, 2014; Hage, 2010). In terms of context of production, according to Macey (2012), Fanon dictated BSWM to Josie, his wife, rather than drafting and editing it. So it was already crafted as a spoken performance, and indeed many of his essays were originally speeches. Such considerations make analysing and classifying his writing more complex.

\section{Pedagogies of subjectification or 'child as method'}

While educationalists from Freire onwards ${ }^{3}$ have drawn on Fanon, this paper's focus on Fanon's ambiguous mobilisation of the child as highlighting his pedagogy of subjectivity attempts a specific contribution. I use the term 'subjectification' to refer to "those forms of conscious and unconscious relation to the self which make us subjects of a certain kind" (Patton 1986, p.24), highlighting the double-sidedness of subjection - as being both subject to and subject of - and so it codes for a socially-contingent and constituted model of subjectivity or experience. Subjectification has acquired a significant feminist educational following, drawing on the work of both Butler (1990; 1997) and Haug (e.g. Davies, 2006). The psychoanalytic and Foucauldian inflections at play highlight the ways competing power relations both produce and constrain 
subjects. This is relevant to the ways pedagogies not only presume, but also shape and produce, particular forms of identity or subjectivity. More generally, as Nayak (2014) puts it in her staging of a discussion between Fanon and Butler via the Black lesbian feminist theorist Audre Lorde, the term helps to link ideology, embodiment and so (to use Butler's, 1997, phrase) the 'psychic life of power', that is, to explore and explain how social structures create psychic structures. 'Pedagogics', of course, not only relate to technical features of teaching but also the address, and corresponding conceptualisation, of the one who is taught, and most often presumed to be the child, or (positioned as) child-like (see also Nandy, 1984). As current discussions of 'the pedagogical state' and governmentality indicate (Pykett, 2012), educational practices permeate social relations implicitly as well as explicitly. Hence pedagogics lie beyond as well as within formal structures of schooling. Like subjectification, or rather as a specific instance of it, pedagogy therefore implicates ideas of self and other, whose relations inscribe every notion of childhood. Ideas of children and childhood inevitably combine sociocultural and political interests, just as they also usher in domains of memory, fantasy and desire (Steedman, 1995). Hence the pedagogical address to the child (or children) has been a site for philosophical subversion (as in Lyotard, 1992; see also Burman, 1998; Hickey-Moody, 2013) and involves attention to irrational, culturally-sedimented ideas as explicit theories (Burman, 2008b, 2015b; Castañeda 2002).

As has been widely noted in a range of educational and philosophical contexts (e.g. Ailwood, 2008; Edelman, 2004), representations of children work rhetorically and politically as tropes figuring futurity, marking investments that include, but are not only, economic (Lister, 2005; 
Hutnyk, 2004). In particular, children figure as prototypical malleable material for the nation whether in terms of prosperity or public order. While claims about children are put to multiple uses, pedagogies link to other key rhetorics and technologies of modernity, involving notions of progress and development. Normative overdeterminations of developmental discourse projected onto the embodied 'growth' and 'growing up' of 'the child' (Burman, 2008; in press a,b; Henderson \& Denny, 2015), as well as figuring within projects of liberation or selfrealisation, equally contribute to the modes of alienation and oppression that Fanon so eloquently described.

Such convergences prompt a proposal of an analytical approach that I call 'child as method'. ${ }^{4}$ This mobilises Chen's (2010) notion of 'Asia as method' to navigate political and analytical binaries between de/colonization, de/imperialization and de/cold war (the latter a key dynamic inflecting receptions and engagements with Marxist analysis) that, as Lin (2012) discusses, offer key resources for conceptualizing knowledge production and transformation. While Fanon's ideas inform Chen's call to take 'Asia as method', here I mobilise 'child as method' to interrogate Fanon's writing, as an instance of the ways 'child' functions politically and rhetorically within national and transnational projects of (neo)colonial, heteropatriarchal, late capitalist expansion. Pressurising further the analogy with colonial discourse (explored, for example, by Nandy, 1984, and Cannella \& Viruru, 2004), rather than rejecting, replacing or displacing dominant discourses of childhood, complicit as they are with the hegemonic neoliberal racist heterosexist order, the strategy here is to explore tensions and frictions indicative of instability, multiplicity and transformative potential. 
The 'method' taken here is to read Fanon both for and via his conceptualisations of children and childhood, attending to political agencies and relationalities so elaborated and evaluating these as resources for the assessment of Fanon's wider cultural-political project. Crucially, in line with Chen's subscription to what he calls Fanon's 'sociopolitical psychoanalysis', this includes an attention to emotional or affective ${ }^{5}$ qualities and dynamics set in play by and around (representations of) children. More specifically, the analytical approach is one of close reading or discursive analysis of attributions of, and conceptualisations of, children and childhoods (cf Burman \& Stacey, 2010; Burman, 2008b; Lesnik-Oberstein, 2010; Caselli, 2010) taking as analytic material Fanon's entire corpus of writing. This may be a 'minor' reading (c.f. Katz, 1996) of Fanon, in the sense of taking up aspects little commented upon, and perhaps at some distance from Fanon's more 'major' themes. Yet it also fruitfully mobilises other meanings of 'minority' that so materially impact on children as politically disenfranchised on the basis of age and as a minor or subordinated social category, and that - arguably - carry significant implications for more general political and educational projects.

Thus 'child as method' becomes a way of reading Fanon, and of engaging Fanon to read 'child'. So while Fanon offers an iconic account of the construction of the subjectivity of the colonized, as the philosopher, Michel Pêcheux put it: "The first requirement consists of giving priority to descriptions of discursive materialities" (Pêcheux, 2014, p.91). Indeed Fanon provided many such descriptions. These crucially focused on his encounter with a French child, but children and education feature across his writings both as subjects and as relational objects. I turn to these descriptions next, firstly addressing Fanon's childhood and how he mobilises some examples in his early writings. 


\section{Fanon as a child}

Especially in BSWM, Fanon draws upon his own childhood as analytical resource and description. Indeed the most authoritative and detailed biography (Macey, 2012) begins with an account of how Martinique, Fanon's birthplace and where he grew up, ${ }^{6}$ is represented in atlases and other educational materials. This point not only indicates the mode of subjectivity Fanon inhabited but also illustrates how curricula mirror colonization practices:

For official purposes, Martinique is in France and its capital is Paris. In French atlases, especially those used in schools, the sheet depicting France often features three insets showing small islands that appear to float in either the western Mediterranean or the Western Approaches to the English channel. Certain maps, including some on display in classrooms, adopt the same convention... The small islands depicted in the insets are, respectively, Martinique, Guadeloupe and Réunion. Martinique and Guadeloupe are in the Caribbean; Réunion is in the Indian Ocean. (Macey, 2012, p.32).

Historically, Martinique was a significant colonial possession for France as a vital source of raw materials - notably sugar, rum, tobacco - and endured a particularly brutal version of the slave trade. After the Second World War Martinicans carried the official status of French citizens, but were scarcely treated as such. ${ }^{7}$ In France, Fanon found himself regarded as an immigrant and foreigner when visiting what was supposed to be his own country.

From a middle class family, Fanon had early acquaintance with the colonial experience of what Macey (2012) describes as "depersonalisation born of what colonial France had been saying to Martinicans for hundreds of years: 'No, no. You're like us. You're French, completely European'" 
(p.63). Fanon offers various examples of the effects of such mixed communications. Especially in his first book, BSWM (Fanon, 1952/1970), Fanon discusses people not identifying as - or even refusing to see themselves as - black, from which he builds his ideas about racial identification and misidentification. ${ }^{8} \mathrm{He}$ also explores modes of identification incited through children's stories and literatures, including how they vilify or pathologise non-Europeans. His examples include ten to fourteen year old Martinican children writing essays in class about their holidays

...like real little Parisians and produced such things as, "I like vacation because then I can run through the fields, breathe fresh air, and come home with rosy cheeks." It is apparent that one would hardly be mistaken in saying that the Antillean does not altogether apprehend the fact of his being a Negro. (BSWM, 1952/1968, Fn., p.115).

Such observations and comments highlight Fanon's project to document and understand how institutional practices, such as schooling, at the level of curriculum as well as everyday social practice, function to install and maintain structures of racialized subjectivity that have profound affective or emotional impacts and investments (Burman, in press a,b).

\section{Fanon and education}

The above examples highlight how specific connections between Fanon and education thematically link pedagogy and subjectification. Indeed, while Fanon has largely figured in postcolonial, political and cultural theory, he is much referred to in discussions of education for decolonisation, in development studies, in discussions of racialised positionings within teacher education and teacher-pupil relations. Fanon's claims about the psychic violence perpetrated in the name of the violation of one's sense of self have also been taken up in discussions of 
multicultural teaching (Allen 2004; Bingham, 2006; Dutro \& Bien, 2014; Leonardo, 2009; Leonardo \& Porter, 2011), of migration and education (Phoenix, 2009), in discussions of bilingual education (Grinberg \& Saavedra, 2000), and - alongside critical race theory and disability studies (Watts \& Erevelles ,2004) - been used to critique flagship national policies on education and social mobility (Wun, 2012). His analyses have also been applied to contemporary international educational policy debates (Shahjahan, 2011), including also the colonisation of the body within educational institutions (Shahjahan, 2014). Taking up Fanon's decolonial project in relation to contemporary discussions of cosmopolitanism, Andreotti (2011) addresses the domain of global citizenship education. His ideas are most widely taken up in terms of forging, reflecting upon and evaluating decolonizing pedagogical approaches (for example, Dei \& Simmons, 2010; Leonardo, 2011; Richardson, 2012).

Fanon's analyses can therefore be read alongside other major educational theorists. His radical humanism (Hallward 2011) connects him with Paulo Freire, his focus on the regulation of subjectivity with Foucault, while many of his ideas resonate with those of Bourdieu. Indeed Bourdieu and Fanon were inspired by the same political context: Bourdieu was sent to do national service in Algeria in 1955, and it was there that he came to abandon philosophy for sociology, and shifted methodologically to ethnography (Bourdieu, 2004; Go, 2013; Yacine, 2004), also inspiring his critiques of education (Calhoun, 2006; Robbins, 1993). While Bourdieu is known to have engaged deeply with Fanon's writings (Calhoun, ibid.), their contributions may better be considered to be complementary - with Fanon addressing better the forms and effects of structural violence (von Holdt, 2013). 
An indication of Fanon's multi-faceted modelling of education, as tool of both oppression and liberation, can be seen in his description of the school (in A Dying Colonialism, p.41, hereafter $D C$, Fanon, 1959/1965) as a key site of counter-acculturation where the politicising role depends on wider sociocultural conditions. ${ }^{9}$ Yet in his final book, Wretched of the Earth (hereafter, WE, Fanon, 1961/1963), Fanon also placed great emphasis on education as a means of decolonization: "To hold a responsible position in an under-developed country is to know that in the end everything depends on the education of the masses, on the raising of the level of thought, and on what we are too quick to call 'political teaching'" (WE, p.159). Yet Fanon clearly envisaged education as a means of democratization and the forging of agentic subjectivities through collective engagement. He wrote: "Now, political education means opening their minds, awakening them, and allowing the birth of their intelligence..." (ibid). He was a rationalist modernist and nationalist, opposing populism and spontaneism. As a significant intervention in anticolonical literary and political discussions of the time, he opposed nostalgic romanticisations of lost pasts, whether of 'negritude' or pan-African culture. Rather he argued: "To educate the masses politically is to make the totality of the nation a reality to each citizen. It is to make the history of the nation part of the personal experience of each of its citizens" (WE, p.161). Here Fanon connects the political with the personal, collective subjectivity with purposeful activity, and an emphasis on the oppressed as holding the means of political transformation.

\section{Fanon and the child}


Educational and social theory treatments of Fanon typically start with his chapter on 'The Fact of Blackness' in BSWM, where Fanon depicts an encounter with a white woman and her child. Despite competing translations, ${ }^{10}$ all focus on his responses to a child taking fright at the sight of him, as a black man, a 'negro', which occasions the traumatic installation of a racialised identity. ${ }^{11}$ This is Macey's (2012) translation (p.164), since he argues that the first English translations included some gross inaccuracies:

"Look, a Negro!" It was an external impetus that flicked me in passing. I smiled slightly. "Look, a Negro!" It was true. I laughed.

"Look, a Negro!" The circle was gradually getting smaller. I laughed openly.

"Mama, see the Negro! I’m frightened!" Frightened! Frightened! Now they were beginning to be frightened of me. I wanted to laugh till I burst, but that had become impossible.'

Having come under attack at several points, the corporeal scheme collapsed giving way to an epidermal racial schema.

This event works as a logical or epistemological moment in the violent imposition and constitution of a racialized subjectivity. As a psychodramatic prototype, it combines "an analysis of a given social-psychological situation and an affective articulation of that same situation" (Hage, 2010, p.113), so conveying the emotional impact and consequences of such treatment. ${ }^{12}$ More likely, it combines equivalent scenarios, although the specificity of arenas cited, in terms of the classing of public space, is worth noting. These are ordinary spaces and routine encounters with ordinary people. It is this sense of contextual embeddedness that leads Macherey (2012) to prefer Fanon over Althusser as a theorist of interpellation. 
The effects are cataclysmic:

On that day, completely dislocated, unable to be abroad with the other, the white man, who imprisoned me, I took myself off from my own presence, far indeed, and made myself an object. What else could it be for me but an amputation, an excision, a haemorrhage that spattered my whole body with black blood? (Fanon, 1952/1968, p.79)

My body was given back to me sprawled out, distorted, re-coloured, clad in mourning that white winter day. (Fanon, 1952/1968, p.80)

From this scenario Fanon elaborated his unique, passionate and powerful account of the experience of the colonized. This is an experience of dehumanization and 'amputation', of 'excision' from ordinary, intuitive corporeality. That is, an experience portrayed as fundamentally distorting the basic relationship with one's physical and psychological being. It is an account that resonates and remains relevant.

This scenario has generated extensive discussion focusing on the whiteness of the woman and the child, and the gendered - and clearly sexed - relationship between the mother and the hypersexualised black man (e.g. Doane, 1999). ${ }^{13}$ There is much to say about this gendered and clearly heterosexed encounter - also 'guaranteed' as heterosexed through the presence of the child (Edelman, 2004) ${ }^{14}$ as well as the various forms and stages of racial (mis)identification this scene depicts or reflects (see also Burman, 2015a), ${ }^{15}$ but, taking up 'child as method', I will stay with the figure of the child in this scene. For, curiously, little has been written about the role of the child in Fanon's writings. ${ }^{16}$ 


\section{Critiquing the imperial child}

Clearly the impacts and responses of this child diverge considerably from the usual child of the western cultural and literary canon. While the latter is typically culturally configured as innocent and pre-social, Fanon's portrayal suggests a subject already complicit and embedded within racism. By reversing the conventional - even expected - model of childhood, the extent and complicity of European culture with racism is emphasised. In this sense, to mobilise a Lacanian trope, it is the message of 'The Emperor's new clothes' in reverse: the child confirms the ideological order on which imperialism is built. The child's innocence does not here reveal a truth that the compliant population is not able to name, or perhaps even see, and so liberates the community from its 'false consciousness'. Rather, here the child 'reveals', by his own implication within it, the social order he is entering. Drawing on an object relations psychoanalytic reading, Lebeau (2005) suggests the child is dealing with its existential fears through subscription to a racist symbolic order: "Slavery, lynching, segregation: with a child's looking and pointing" (Lebeau, 2005 p.131).

In Fanon's account, the child becomes increasingly qualified via the escalating fear and racialised attributions Fanon documents. Fanon names the child, firstly, as a "boy", then as "the little boy", then as "the handsome little boy", and finally as "the little white boy" who "throws himself into his mother's arms' out of fear of being eaten" (Fanon, 1952/1968 BSWM p.81). As discussed elsewhere, Burman, 2015a, astonishingly, Bhabha, in his influential 1983 analysis, presumes the child to be a girl so betraying either a significant underattention to gender or, worse, a presumption of the attributed transcendent feminised subject position of 'the child'. 
A closer reading indicates more. For what commentators fail to address is that it is not the mother who is qualified as white, but the child; the child who is a "little boy", a "handsome little boy" and, finally, a (or, rather, 'the ${ }^{17}$ ) "little white boy". It is as if, in the proliferation of qualifications, Fanon is conveying the frantic sense of striving for categorization, for meaningmaking, and so connection with the other, and so (according to his existential and psychoanalytic model) to confirm himself. Crucially, the assignation of the white/black relation occurs as a function of Fanon's reaction to the child's reaction to him: the child names him as 'a Negro' and says he is 'frightened', which produces in Fanon a rupture of worldview that divides him as black from the child as white, and thereby from his previous understanding of himself. The key point here is that it is only after this final qualification of the little, handsome boy as "white" that Fanon "become[s] aware of my uniform. I had not seen it" (BSWM, 1952/1968 p.81), that is, his black skin, and experiences a sense of burning and implosion from "all this whiteness". ${ }^{18}$ The specific relation to the child marks the pivotal moment.

\section{Fanon's children beyond Black Skin, White Masks}

Iconic as this scene has become for colonial and postcolonial discussions, the child of 'Look, a Negro!' is only one of various children populating Fanon's texts. Fanon used a wide repertoire of child associations, as well as referring to children as exercising subjectivity and agency in their own right. Having identified, categorised and analysed these across his four texts (see also Burman, in press a), I suggest these can be classified in three ways as: 1 . The metaphorical child;

2, The gendered and generationally ordered child; and (what might be called ${ }^{19}$ ) 3. Empirical children. These categories were developed from a close reading of Fanon's writings alongside 
an immersion in critical childhood and educational literatures (some of which are already referenced here), in particular those which explore the political work 'child' and 'children' do within conceptual and policy discussions. Given prevailing discourses of childhood, there is nothing particularly surprising about this typology. Rather more interesting are the sharp political differentiations that emerge from Fanon's allocations and distributions of qualities associated with children according to their positioning in relation to colonialism.

\section{The metaphorical child}

To illustrate the metaphorical child, I will examine two indicative examples from Fanon's final book, Wretched of the Earth. Unsurprisingly, given his position as a secular modernist, Fanon here adopts a traditional progressivist model where the narrative of individual development is transposed to that of the new postcolonial nation state. Beyond this, Fanon reverses the traditional, linear, lifecourse equation between individual and national development as triumphal or inevitable and turns this around by mobilising the discourse of the 'unnatural' in the service of political critique. In 'Pitfalls of national consciousness', he criticizes the developing national bourgeoisie for emulating its western former masters, suggesting that this reverses a natural developmental path: "We need not think that it is jumping ahead; it is fact beginning at the end. It is already senile before it has come to know the petulance, the fearlessness or the will to succeed of youth "(p. 123).

Moreover, in contrast to receptions of his writing that accuse him of inciting and celebrating violence, ${ }^{20}$ it is clear that Fanon's primary concern was to understand the impacts of the violence and distortions done to the oppressed/colonized, and to oust these inner psychic 
reproductions of the colonial state. As William Pinar (2011) notes, Fanon interrogates connections between models of individual and social authority as reproduced within colonial relations: "This intrapsychic violence of civic self-formation was evident not only in colonized regions, but in the colonizing nation states themselves" (p.46). Fanon destabilises the affective ties of colonized to colonizer, addressing the condition of the 'native intellectual' who is oriented to western culture. He mobilizes a discourse of misplaced 'adoption', not merely to privilege naturalised biological kinship (aligned to national belonging), but rather to foreground the role of insecure roots or foundations: "Like adopted children who only stop investigating the new family framework at the moment when a minimum nucleus of security crystallizes in their psyche, the native intellectual will try to make European culture his own." (WE, p.176).

\section{The gendered and generationally ordered child.}

Recent discussions in childhood studies have emphasised how childhood is a relational category, such that generational order and positioning need to be taken into account (Alanen, 2000). Applying this to Fanon's discussion of family relationships, in $D C$ he devotes considerable attention to exploring the impacts of both colonialism and anticolonial struggle on generational relations. Further, Fanon's treatment of women, especially young women, has generated much debate, in particular the essay 'Algeria unveiled'. This concerns the changing relational meanings of adopting and shedding the veil - as well as the motif of the violation and resistance strategies of the feminised body of the nation. Yet even as Fanon interrogates and in part explains the elision between woman and nation, he nevertheless reproduces this in the very title of the essay (see also Haddour, 2010, for further analysis of the role of both the rhetoric 
and enforced practices of unveiling ). 'Algeria Unveiled' ends with "Side by side with us, our sisters do their part in further breaking down the enemy system and in liquidating the old mystifications once and for all" (DC, p.67). This allots a key place to women but also treats them as separate (from 'us'), and as somehow endowed with greater responsibility for "liquidating the old mystifications."

\section{Empirical children}

Alongside both mobilising and subverting the metaphorical repertoire of childhood, Fanon also discussed chronological children and young people. In a prescient critique of the capitalist notion of sport and the commodification of black bodies, reflecting his general perspective on racism as fetishism (see also Bhabha, 1983), he commented: "The youth of Africa ought not to be sent to sport stadiums but into the fields and into the schools" ('Pitfalls of National Consciousness', WE, p.158). He describes the young as impressionable and open to manipulation by "the various assaults made upon them by the very nature of Western culture" (ibid., p.157-8). Yet in his 'Letter to the Youth of Africa' (in the collection of his political writings published posthumously, Fanon, 1964), there are no chronological, child or youth-related references. Instead, Fanon focuses on addressing agentic national subjects, whose responsibilities are the same, whatever their age.

Where Fanon mobilises a discourse of vulnerability, this appears not to install passivity but rather threat. His documentation of the suffering, brutalization and militarization of children and young people offers clear examples. In WE, Fanon, the psychiatrist, ${ }^{21}$ mobilizes the genre of medical case histories to catalogue psychological casualties and disturbances created by both 
chronic colonial repression and the horrific massacres, battles and torture with which the revolutionary struggle was met.

Children figure in some of these 'Cases'. 'Series B, Case 1' reports the murder by two Algerian boys, thirteen and fourteen years old respectively, of their European playmate. Fanon presents, apparently verbatim, the cross examination of these boys (who admitted the crime), and the efforts to establish whether they knew what they were doing, to establish a motive, only to hear that there was none ("'We weren't a bit cross with him... He was a good friend of ours.'" $W E$, p.217) except the pent-up desire to kill a European. He quotes them as saying: "'One day we decided to kill him because the Europeans want to kill all the Arabs. We can't kill big people. But we could kill ones like him, because he was the same age as us..."' (ibid., p.217-8). This offers a chilling indication of the depersonalisation and psychic splitting generated by war, for these two boys seem rational in their claims, even though they could see no contradiction between the European boy being their friend and deciding to kill him. Here Fanon appears to mobilise a more conventional pedagogy of childhood as a warning to Europeans about the farreaching effects, not only caused by war but also of psychic assaults on identity.

Yet while Fanon's account appears to portray the boys as rational, in the sense that they knew what they were doing, what remains unclear is where the responsibility lies. Clearly a traditional developmental psycho-legal reading (see Cordero Arce, 2015) would typically consider the children as children and so by definition incapable of being held responsible for their murderous action. Or, as has been the case in landmark legal judgments both the UK in the 1990s (McDiarmid, 2013) and currently being debated in India, the perpetrator(s) are 
considered no longer to qualify as children and so can be held legally responsible. But this would be to maintain a clear individual-social binary, and so return questions of responsibility to matters of individual motivation or intent. Rather what Fanon implies is that - once we admit the impacts and effects of psychic suffering and brutalization - such actions, including on the part of children, can become not only comprehensible but perhaps even expected. The accusation therefore shifts from being attached to the boys and their crime, that is, it is detached from questions of individual responsibility, to qualify instead sociopolitical processes and practices, including the perpetrators of colonialism and even more broadly those who allow its atrocities to occur. Indeed, it should be noted that minoritized children continue to be more often held to account through notions of 'individual responsibility' in ways that precisely 'forget' or overlook the ways race or racialisation has marked the production of which children are considered to be 'threats' in the first place. Such dynamics are especially evident in relation to child soldiers (whose situation, arguably the two boys can be considered relevantly alongside), with the dominant narrative focus on stolen or violated childhood typically works to reinstall and even naturalise the modern western model (Coundouriotis, 2010).

\section{Which child?}

Rather than presuming a universal, transhistorical or transcendent 'child' that warrants not only a pre-social but also a culturally and gender-specific model of childhood masquerading as general (Burman, 2008b; Levander, 2005), critical analysts and activists around childhood have called for attention to its diverse locations and performances (Boyden, 1990; Taylor, 2013). The diversity of ways Fanon figured children and childhood both poses key political questions and 
also connects with other recent conceptual-political debates on childhood, subjectivity and pedagogy.

First, discernible in his complex pedagogics of childhood is a hope, as well as demand, for a different kind of recognition; inviting the child to be a teller of a different kind of truth, as harbinger of a changing, less racist, world. From this reading of 'child as method' I suggest Fanon's diverse metaphorizations of childhood, as identified across his writings, support this reading.

Second, queer theorists have connected Fanon's analyses with educational processes (e.g. Pellegrini, 2008; Pinar, 2011), suggesting convergences. ${ }^{22}$ Pinar (2011) in particular mobilises Fanon as a key theorist linking projects of subjective constitution, critical deconstruction and reformulation with collective possibilities. Moreover, Lee Edelman's (2004) call to refuse the racial-national agenda of futurity and progress embodied by the figure of the child invites another reading. This narrative is of the child seeking out a homosocial connection with Fanon, that neither bolsters patriarchy in the repudiation of the feminine, the $(m)$ other, nor installs 'race' as difference, nor ushers in the now all prevailing suspicion of sexual abuse. Could the displacement of the woman-man relationship by this (male)child-man focus - albeit one that invokes the position of the woman as securer of the racial as well as gendered order - be read as destabilising or, alternatively, as confirming prevailing generational power relations that dismiss or devalue children's agencies? While some commentators have analysed Fanon's socalled 'primal scene' as a disavowal of sexual difference indicative of his unacknowledged feelings about his own Creole Antillean heritage (with its links to slavery and the rape of black 
women) (Vergès, 1997), others have focused on his politics of solidarity and an open, as yet undetermined, future temporality:

...Fanon provides an important model for theorizing affiliation beyond the boundaries of nation and race. Fanon's new nation occupies the time of the future (he expresses it as a wish for what is yet to come); the past, while important, does not determine the nation's shape. (Musser, 2012 p.90)

A third interpretation, following Macherey (2012), sees the child as a cypher, a mere placeholder, in the psychodrama of "Look, a Negro!". This invites consideration of what kind of 'other' the child is a proxy for. Yet it seems that no other category of person could have fulfilled this role, for its power relies precisely on representations of the child as (heteropatriarchallyfigured) extension of 'his' mother and white society, whether as (willing or automaton) reproducer of it, or casualty of it. In this sense, no other kind of 'other' could have been mobilised. It seems that, for Fanon, ultimately the child as child is figured as both competent in, yet not fully aware or responsible for, the reproduction of racism and so, paradoxically, 'his' subjectivity is also of diminished interest.

The child of "Look, a Negro!", rather than being tied to a specifically defined future, remains underwritten, inscrutable and perhaps unreadable. It is destabilised, unmoored from its conventional readings, while at the same time endowed with 'his' own 'development-free' space (Motzkau,2009) that therefore puts into question dominant developmental discourses. Fanon's narrative portrays the child as elided with the $(\mathrm{m})$ other as the collective other, the 'they' who 'were beginning to be frightened of me'. While this clearly risks the imposition of 
another - now familiar - orientalism (transferred from colonialised people to a colonised lifestage), this lack of determinacy can also be read in relation to the constrained dystopic, 'apocalyptic', but also still open, postcolonial moment to which Fanon directs his pedagogics of childhood.

\section{Transformation}

Dei (2010 p.xxii) describes transformative education as concerned with practices of consciousness raising, linking decolonization with self-transformation as well as resistance. Fanon's linked the psychic, subjective and the political, with particular reference to colonialism and the construction of racialisation, via his representations of childhood. Even if his various treatments admit no easy resolution this focus on 'child as method', in highlighting the diversity of Fanon's repertoire of discursive tropes of the child, poses the question of what an anti-colonial or revolutionary metaphorics of childhood might look like. Such a metaphorics attends to specific places, processes and relationships - which also has consequences for the role of education in this. This is an approach to pedagogy that highlights the role of emotions, fantasies, and intersubjective relations, as central to as well as alongside collective mobilisations (Burman, 2016).

My analysis here suggests that Fanon was as much a deconstructionist - in his playful use of familial/relational/generational discourses (reversing prevailing understandings of aged, chronological, as well as sexed/gendered and other power relations) as he was a modern developmentalist, formulating policies to turn the young of the nation into 'mature' ('conscious', 'responsible') adults. These concepts accompany a psychoanalytically-inflected 
perspective on childhood experience as formative for dystopian (traumatically 'apocalyptic ${ }^{23}$ ) future social-political relations, as indicated by the 'empirical' examples from WE.

Yet 'empirical' and 'metaphorical' figurations of childhood do not function independently, but rather the former rely upon the latter. It could be argued that, in his iconic encounter with the white French mother and child, Fanon mobilised the moral culpability of a child 'already' tainted by racism as a way of representing its hideousness. This evocation of a sense of 'untimeliness' - out of time or before his 'natural' time - works to emphasise the grotesque distortion of the child's social-symbolic coordinates as well as its interpellations for Fanon, the now blackened, man. But alongside this apparent return to a nostalgic moment of child purity, it is important that Fanon neither resorted to de-cried the lost innocence of the child (which would re-install a traditional metaphorics of childhood). Nor did he complain of the humiliation of being hurled into existential nausea as an object of fear by a child because of 'the fact of blackness' (or the lived experience of being positioned within a black body). For better or worse, as in his other depictions of dangerous and damaged children and childhoods, Fanon accorded significant social subjectivity - agency, participation - to children, while his figurations (Castaňeda, 2002) of the child offer significant sources of suspension or interruption (c.f. Gaztambide-Fernández, 2010) to dominant models.

Taking 'child as method' may import further resonances both for and beyond Fanon's political project. Fanon's politicisation and engagement in the Algerian revolution (of 1954-62), which was so bloody and brutal, carries resonances with the revolutions some 60 years later in the 'Arab spring' of the 2010s. Here too naturalised motifs of the child (or youth) have been 
mobilised - whether as quintessential victims or as agents of revolutionary change - alongside the increasing empirical reality of young people as a greater demographic proportion of poor, less-'developed' countries. As Gilroy (2010) noted, Fanon's analyses are also prescient of current national and transnational securitization agendas. Given the recent setbacks to democratic secular processes across the Arab world, as elsewhere, we might also notice some of the gendered dynamics associated with these moves that Fanon's account anticipated. Even as the second Gulf War was cynically justified in the name of 'rescuing brown women from brown men' (Spivak, 1988), with claims of women's emancipation functioning to legitimate imperialism, so we need to worry about the trope of 'girl power' increasingly being mobilised by World Bank (Kaffmann \& Gill, 2014). The presentation of the girlchild as pliable prototypical neoliberal subject and as beneficiary of western aid is a troublesome political trope, which Bhabha's misreading of the child in BSWM as female perhaps anticipates even as it also installs the heterosexual matrix. Fanon's figuration of the child as a boy therefore perhaps offers some further resources.

Indeed, as the trail of citations in educational journals suggest, Fanon's analyses of these dynamics remain conceptually vital and methodologically relevant. Perhaps, though, he was most compelling in showing the psychic impacts of colonial repression and war, of the hollowing out of humanity by powerlessness, dispossession, resentment and enforced idleness produced by colonisation. These psychoaffective conditions, that is, the socially-produced psychological consequences of alienation, depersonalisation and other forms of traumatic distress, were rhetorically conveyed through his representations of childhood, both in terms of attributed qualities but even more importantly in terms of relations towards children. In this 
sense, then, Fanon's work was and is psychopolitical and educational, not only in offering descriptions of how certain psychic states (of racialized suffering or oppression) have come about, but also in exploring and evoking the conditions for their transcendence. As with much feminist analysis, Fanon's performative or pedagogical psychopolitics, a politics of psychological and psychoeducational practice expressed via his ambivalent and variable portrayal of children and childhood, aimed to prefigure psychic transformation through a liberation struggle that not only connects the political and the personal, but also combines solidarity with revolutionary struggle.

\section{REFERENCES}

Ailwood, J. (2008). Learning or earning in the "Smart State". Childhood: a global journal of child research 15(4), 535-551.

Alanen, L. (2005). Childhood as generational condition. In C. Jenks (Ed.) Childhood: Critical Concepts in Sociology Volume 3 (pp. 286-305). London: Routledge.

Alessandrini, A. (1997). Whose Fanon?. Minnesota Review, 48-9, 235-242.

Allen, G. (2011a). Early Intervention: the next steps. http://media.education.gov.uk/assets/files/pdf/g/graham\%20allens\%20review\%20of\%2 Oearly\%20intervention.pdf

Allen, G. (2011b). 'Early Intervention: smart investment, massive savings', https://www.gov.uk/government/publications/early-intervention-smart-investmentmassive-savings 
Allen, R. L. (2004). Whiteness and critical pedagogy. Educational Philosophy and Theory, 36(2), 121-136.

Baldwin, J. (1955/1984). Notes of a native son. New York: Beacon Press.

Bingham, C. (2006). Before recognition and after: the educational critique. Educational Theory and Philosophy 56(3), 325-344.

Bhabha, H. (1983). The other question: the stereotype and colonial discourse. Screen 24(6), 18 36.

Bhabha, H. (1994). Interrogating identity: Frantz Fanon and the postcolonial prerogative. In The Location of Culture (pp.40-65). New York: Routledge.

Boyden, J. (1990). Childhood and the policymakers: A comparative perspective on the globalization of childhood, In A. James \& A. Prout (Eds) Constructing and Reconstructing Childhood (pp.196-210). Lewes: Falmer Press.

Bourdieu, P. (2004). Algerian landing. Ethnography, 5, 415-443.

Bulhan, H. A. (2004). Frantz Fanon and the psychology of oppression. New York: Springer.

Burman, E. (1998). Pedagogics of post/modernity: the address to the child in Walter Benjamin and Jean-Francois Lyotard. In K. Lesnik-Oberstein (Ed.) Children in Culture: approaches to childhood (pp.55-88). New York/London: Macmillan.

Burman, E. (2008a). Deconstructing Developmental Psychology, London: Brunner-Routledge. $\left(2^{\text {nd }} E d\right)$

Burman, E. (2008b). Developments: child, image, nation. London: Brunner-Routledge.

Burman, E. (2008c). Resisting the deradicalization of psychosocial analyses. Psychoanalysis, Culture \& Society, 13(4), 374-378. 
Burman, E (2012). Deconstructing neoliberal childhood: towards a feminist antipsychological approach. Childhood: a global journal of child research, 19(4), 423-438.

Burman, E (2013). Conceptual resources for questioning child as educator. Studies in Philosophy and Education, 32 (3), 229-243.

Burman, E. (2015a). Fanon's Lacan and the traumatogenic child: psychoanalytic reflections on the dynamics of colonialism and racism. Theory, Culture \& Society, doi: $10.1177 / 0263276415598627$

Burman, E. (2015b). Knowing Foucault, Knowing You: 'raced'/classed and gendered subjectivities in the pedagogical state', Pedagogy, Culture \& Society, DOI: $10.1080 / 14681366.2015 .1057215$

Burman, E. (2016) 'Lessons in the psychology of learning and love/ Lecciones de la psicología del aprendizaje y el amor', Psicoperspectivas, 15, 1: 17-28, http://www.psicoperspectivas.cl/index.php/psicoperspectivas/article/viewFile/666/450

Burman, E (in press a). Fanon's Other Children: psychopolitical and pedagogical implications. Race, Ethnicity \& Education

Burman, E. (in press, b).Fanon, Foucault, Feminisms: Psychoeducation, theoretical psychology and political change. Theory \& Psychology

Burman, E. and Stacey, J. (2010). The child and childhood in feminist theory. Feminist Theory, $11(3), 227-240$

Butler, J. (1990). Gender trouble. New York: Routledge. 
Butler, J. (1997). The Psychic Life of Power. New York and London: Routledge.

Calhoun, C. (2006). Pierre Bourdieu and social transformation: lessons from Algeria. Development and Change, 37(6), 1403-1415.

Caselli, D. (2010). Kindergarten theory: Childhood, affect, critical thought. Feminist Theory, $11(3), 241-254$.

Castaňeda, C. (2002). Figurations: child, bodies, worlds. Durham and London: Duke University Press.

Cannella, G. \& Viruru, R. (2004). Childhood and postcolonization. New York: Routledge.

Chen, K,H. (2012). Takeuchi Yoshimi's 1960 'Asia as method' lecture. Inter-Asia Cultural Studies, 13(2), 317-324.

Chen, K. H. (2010). Asia as method: Toward deimperialization. Durham: Duke University Press.

Cordero Arce, M. (2015). Maturing Children's Rights Theory. The International Journal of Children's Rights, 23(2), 283-331.

Coundouriotis, E. (2010). The Child Soldier Narrative and the Problem of Arrested Historicization', Journal of Human Rights, 9(2), 191-206.

Davies, B. (2006). Subjectification: the relevance of Butler's analysis for education. British Journal of Sociology of Education, 27(4), 425-438.

De Lissovoy, N. (2010). Staging the crisis: teaching, capital, and the politics of the subject. Curriculum Inquiry, 40(3), 418-435.

De Oliveira, A. V. (2011). (Towards) decoloniality and diversality in global citizenship education. Globalisation, Societies and Education, 9(3-4), 381-397. 
Dei, G. J. S. (2010). Rereading Fanon for his pedagogy and implications for schooling and education. In G. J. S. Dei \& M. Simmons,(Eds.), Fanon \& Education: thinking through pedagogical possibilities (pp.1-28). New York: Peter Lang.

Dei, G. J. S \& Simmons, M. (2010). The pedagogy of Fanon: an introduction. In G. J. S. Dei \& M. Simmons (Eds.) (2010) Fanon \& Education: thinking through pedagogical possibilities (p.p. xiii-xxv).. New York: Peter Lang.

Dei, G. J. S. \& Simmons, M. (Eds.) (2010). Fanon \& Education: thinking through pedagogical possibilities. New York: Peter Lang.

Desai, M. U. (2014). Psychology, the psychological, and critical praxis: a phenomenologist reads Frantz Fanon. Theory \& Psychology, 24, 1: 58-75.

Doane, M. A. (1999). Dark continents: epistemologies of racial and sexual difference in psychoanalysis and the cinema. In J. Evans \& S. Hall (Eds.) Visual Culture: the reader (pp.448-456). London: Sage.

Dutro, E. \& Bien, A. (2014). Listening to the Speaking Wound: A Trauma Studies Perspective on Student Positioning in Schools. American Educational Research Journal, 51(1), : 7-35.

Edelman, L. (2004). No Future. Durham: Duke University Press.

Ellison, R. (1952) Invisible Man. New York: Random House.

Fanon, F. (1952/1970). Black skin, white masks. (Translated by C. L. Markmann) London: Paladin.

Fanon, F. (1959/1965). A Dying Colonialism (Translated by H. Chevalier). New York: Grove Press. Fanon, F. (1961/1963). The Wretched of the Earth. (Translated by C. Farrington). London: Penguin. 
Fanon, F. (1964/1967). Toward the African revolution: political essays. (Translated by H.

Chevalier). New York: Grove Press.

Frosh, S., \& Baraitser, L. (2008). Psychoanalysis and psychosocial studies. Psychoanalysis, Culture \& Society, 13(4), 346-365.

Gates, H. L. (1991). Critical Fanonism. Critical Inquiry, 17(3), 457-470.

Gaztambide-Fernández, R. (2010). Interruption and imagination in curriculum and pedagogy, or how to get caught inside a strange loop. Curriculum Inquiry, 40(3), 409-417.

Gilroy, P. (2010). Fanon and Améry: theory, torture and the prospect of humanism. Theory, Culture \& Society, 27(7-8), 16-32.

Go, J. (2013). Decolonizing Bourdieu: colonial and postcolonial theory in Pierre Bourdieu's early work. Sociological Theory, 31(1), 49-74.

Grinberg, J. \& Saavedra, E. (2000). The constitution of bilingual/ESL education as a disciplinary practice: genealogical explorations. Review of Educational Research, 70, 419-441.

Haddour, A. (2010). Torture unveiled: rereading Fanon and Bourdieu in the context of May 1958. Theory, Culture \& Society, 27(7-8), 66-90.

Hage, G. (2010). The affective politics of racial mis-interpellation. Theory, Culture \& Society, 27(7-8), 112-129.

Hallward, P. (2011). Fanon and political will. Cosmos and History: the Journal of Natural and Social Philosophy, 7(1), 104-127.

Hansen, W. \& Musa, U.(2013). Fanon, the Wretched and Boko Haram. Journal of Asian and African Studies, 48(3), 261-296.

Haug, F. (1987). Female Sexualisation. London: Verso. 
Henderson, J., \& Denny, K. (2015). The resilient child, human development and the "postdemocracy". BioSocieties. DOI: 10.1057/biosoc.2014.24

Hickey-Moody, A. C. (2013). Deleuze's children. Educational Philosophy and Theory, 45(3), 272286.

Hook, D. (2012). A Critical Psychology of the Postcolonial: the Mind of Apartheid. New York: Routledge.

Hook, D. (2005). A critical psychology of the postcolonial. Theory \& Psychology, 15(4), 475-503. Hudis, P. (2015). Frantz Fanon: philosopher of the barricades. London: Pluto Press. Hutnyk, J. (2004). Photogenic poverty: souvenirs and infantilism. Journal of Visual Culture, 3(1), 77-94.

Kaffman, O. \& Gill, R. (2014). "The revolution will be led by a 12-year-old girl": girl power and global biopolitics. Feminist Review, 105, 83-102.

Katz, C. (1996). Towards minor theory. Environment and Planning D: Society and Space, 14(4), 487-499.

Khanna, R. (2004). Dark Continents: psychoanalysis and colonialism. Durham: Duke University Press.

Khanna, R. (2013). The lumpenproletariat, the subaltern, the mental asylum. The South Atlantic Quarterly, 112(1), 129-143.

Lacan, J. (2006). Logical time and the assertion of anticipated certainty. In Ecrits. (trans. B. Fink) (pp.161-175). New York and London: Norton.

Lebeau, V. (2005). Children of violence. In M. Silverman (Ed.) Frantz Fanon's Black Skin White Masks: interdisciplinary essays (pp.128-145). Manchester: Manchester University Press. 
Leonardo, Z. \& Porter, R. (2010). Pedagogy of Fear: Toward a Fanonian Theory of Safety in Race Dialogue," Race, Ethnicity \& Education 13(2),139-157;

Leonardo, Z. (2011). After the glow: race ambivalence and other educational prognoses. Educational Philosophy and Theory, 43(6), 675-698.

Lesnik-Oberstein, K. (2010). Childhood, queer theory, and feminism. Feminist Theory, 11(3), 309-321.

Levander, C. (2006). Cradle of liberty: Race, the child, and national belonging from Thomas Jefferson to WEB Du Bois. Durham: Duke University Press.

Lin, A. M. (2012). Towards Transformation of Knowledge and Subjectivity in Curriculum Inquiry: Insights From Chen Kuan-Hsing's “Asia as Method”. Curriculum Inquiry, 42(1), 153-178.

Lister, R. (2005). Investing in the citizen workers of the future. In H. Hendrick (Ed.) Child Welfare and Social Policy (pp.449-462). Bristol: The Policy Press.

Keller, R. (2007). Clinician and revolutionary: Frantz Fanon, biography, and the history of colonial medicine. Bulletin of the History of Medicine, 81(4), 823-841.

McDiarmid, C. (2013). An age of complexity: Children and criminal responsibility in law. Youth justice, 13(2), 145-160.

Macey, D. (2010). "I am my own foundation": Franz Fanon as a source of continued political embarrassment. Theory, Culture \& Society, 27 (7-8), 33-51.

Macey, D. (2012). Frantz Fanon: a biography. London: Verso.

Macherey, P. (2012). Figures of interpellation in Althusser and Fanon. Radical Philosophy, 173: $9-20$

Mazzei, L. A. (2007). Inhabited silence in qualitative research: Putting poststructural theory to work. New York: Peter Lang. 
Menozzi, F. (2015). Fanon's Letter: Between Psychiatry and Anticolonial Commitment. Interventions, 17(3), 360-377.

Motzkau, J. F. (2009). The semiotic of accusation: Thinking about deconstruction, development, the critique of practice, and the practice of critique. Qualitative Research in Psychology, 6(1-2), 129-152.

Murard, N. (2008). Psychothérapie institutionnelle à Blida. Tumultes, 31(2), 31-45.

Musser, A. J. (2012). Anti-Oedipus, Kinship, and the Subject of Affect Reading Fanon with Deleuze and Guattari. Social Text, 30(3 112), 77-95.

Nandy, A. (1984). Reconstructing childhood: A critique of the ideology of adulthood. Alternatives, 10(3), 359-375.

Nayak, S. (2014). Race, Gender and the Activism of Black Feminist Theory: Working with Audre Lorde. London: Routledge.

Oliver, K. (2004). The colonization of psychic space: A psychoanalytic social theory of oppression. Minnesota: University of Minnesota Press.

Patton, P. (1986). Deleuze and Guattari: ethics and post-modernity', Leftwright: Intervention, $20,24-34$

Pellegrini, A. (2008)."What Do Children Learn at School?" Necropedagogy and the Future of the Dead Child. Social Text, 26(4), 97-105.

Phoenix, A. (2009). De-colonising practices: negotiating narratives from racialised and gendered experiences of education. Race, Ethnicity \& Education 12(1), 101-114;

Pinar, W. (2011). The character of curriculum studies. New York, NY: Palgrave Macmillan Pykett, J. (Ed.) (2012). Governing Through Pedagogy. London: Routledge. 
Rabaka, R. (2011). Revolutionary Fanonism: On Frantz Fanon's modification of Marxism and deconolonization of democratic socialism. Socialism and Democracy, 25(1): 126-145.

Razanajao, C.L. Postel, J. \& Allen, D.F. (1996). The life and psychiatric work of Frantz Fanon. History of Psychiatry, 7, 499-524.

Richardson, T. (2012). Disrupting the coloniality of being. Towards de-colonial ontologies in the philosophy of education. Studies in the Philosophy of Education, 31(5), 539-551.

Robbins, D. (1993). The practical importance of Bourdieu's analyses of higher education. Studies in Higher Education, 18(2), 151-163.

Shahjahan, R. (2011). Decolonising the evidence-based education and policy movement: revealing the colonial vestiges in educational policy, research, and neoliberal reform, Journal of Educational Policy, 26(2), 181-206.

Sikuade, A. (2012). Fifty years after Frantz Fanon: beyond diversity. Advances in psychiatric treatment, 18(1), 25-31. http://apt.rcpsych.org/content/18/1/25.full (accessed 030715)

Spivak, G.C. 1993. Can the subaltern speak?. In P. Williams and L. Chrisman (Eds.) Colonial Discourse and Post-Colonial Theory (pp.66-112). London: Harvester Wheatsheaf.

Steedman, C. (1995). Strange dislocations: Childhood and the idea of human interiority, 17801930 London: Virago.

Stockton, K. (2009). Growing sideways. Durham: Duke University Press.

Stoler, A. L. (2002). Carnal knowledge and imperial power: Race and the intimate in colonial rule. Berkeley: Univ of California Press.

Taylor, A. (2013). Reconfiguring the natures of childhood. London: Routledge. 
von Holdt, K. (2013).The violence of order, orders of violence: between Fanon and Bourdieu. Current Sociology, 61(2), 112-131.

Vergès, F. (1996).The heritage of Frantz Fanon. The European Legacy, 1(3), 994-998.

Vergès, F. (1997). Creole skin, Black mask: Fanon and disavowal. Critical Inquiry, 23(3), 578-596.

Watts, I. E. \& Erevelles, N. (2004.) These Deadly Times: Reconceptualizing School Violence by Using Critical Race Theory and Disability Studies. American Educational Research Journal, 41(2), 271-299.

Weiler, K. (1996). Myths of Paolo Friere. Educational Theory, 46 (3), 353-371.

Wun, C. (2012). The anti-Black order of No Child Left Behind: Using Lacanian psychoanalysis and critical race theory to examine NCLB. Educational Philosophy and Theory, DOI: 10.1080/00131857.2012.732011.

Yacine, T. (2004). Pierre Bourdieu in Algeria at war: notes on the birth of an engaged ethnosociology. Ethnography, 5(4), 487-509.

Zembylas, M. (2015). Re-thinking race and racism as technologies of affect: theorizing the implications for anti-racist politics and practice in education. Race Ethnicity and Education, 18(2), 145-162.

\footnotetext{
${ }^{1}$ I discuss later Vergès' (1997) psychobiographical analysis of why Algeria rather than Martinique became Fanon's primary arena for political struggle.

2 The four texts Fanon authored are: Black Skin, White Masks (1952/1970), A Dying Colonialism (1959/1965), Wretched of the Earth (1961/1965) which were all published in his lifetime, while a posthumous collection of his political writings was published in 1964 (translated in 1967) entitled Toward the African revolution: political essays.

${ }^{3}$ Indeed Weiler (1996, p.359) suggests that Friere was inspired by Fanon.

${ }^{4}$ Elsewhere I discuss 'child as educator' (Burman, 2013).
} 
${ }^{5}$ While I recognise that current accounts distinguish between 'emotion' and 'affect', in particular mobilising the latter to bring in less cognitive and material features, in line with Fanon's own writing which both argues for and offers in its practice a synthesis across the material-political-subjective-embodied, I retain both terms for ease of reading and to avoid anachronism.

${ }^{6}$ Macey makes much of the ways commentators fail to acknowledge or address Fanon's Martinican background, and its significance for understanding his engagement in Algeria, highlighting the "eradication of the specifically French and Martinican dimensions of Fanon's colonial experience." (2012, p.28)

${ }^{7}$ As Macey (2012, p.33) notes: "One could read Le Monde or any other French newspaper for a long time without realizing that Martinique is in France. Inclusion goes hand in hand with exclusion."

${ }^{8}$ As an account of the psychological development of an imposed black identity, alongside claims of elucidating subconscious and unconscious features of the black/colonized psyche, it is not surprising that Fanon mobilises a psychoanalytic frame See Burman (2015) for a detailed discussion of Fanon's relationship to and use of Lacanian ideas, including the 'mirror stage'.

9 "Specialists in basic education for underdeveloped countries or technicians for the advancement of retarded societies would do well to understand the sterile and harmful character of any endeavor which illuminates preferentially a given element of the colonized society. Even within the framework of a newly independent nation, one cannot attack this or that segment of the cultural whole without endangering the work undertaken (leaving aside the question of the native's psychological balance). More precisely, the phenomena of counter-acculturation must be understood as the organic impossibility of a culture to modify any one of its customs without at the same time re-evaluating its deepest values, its most stable models. To speak of counter-acculturation in a colonial situation is an absurdity. The phenomena of resistance observed in the colonized must be related to an attitude to a cultural, hence national, origination." ('Algeria Unveiled', p.41-2)

${ }^{10}$ Macey $(2010 ; 2012)$ claims there are many inaccuracies within Charles Markmann's first translation of the English edition, which he also argues (Macey, 2012) have contributed to particular Americanized readings of Fanon which have occluded the significance of his French and Martinican backgrounds.

${ }^{11}$ The French word 'négre' is not equivalent to the (American) English 'negro', and is (even) more insulting (Macey, 2012).

${ }^{12}$ Macey sets the scene in a park, while Markmann's (and also Hage's, 2010) narrative marks the setting as in a train. (Fanon's text mentioned both.)

${ }^{13}$ As a notable example: "For Fanon, a psychoanalytic understanding of racism hinges on a close analysis of the realm of sexuality. This is particularly true of black-white relations since blacks are persistently attributed with a hypersexuality. Why is it sexuality which forms a major arena for the articulation of racism? From a psychoanalytic point of view, sexuality is the realm where fear and desire find their most intimate connection, where notions of otherness and the exotic/erotic are often conflated. Whether heterosexual or homosexual, sexuality is generally thought to be indissociable from the effects of polarization and differentiation, often linking them to structures of power and domination." (Doane, 1999, p. 451)

${ }^{14}$ Moreover this presence also precisely wards off the encounter as primarily constituted by, but also recapitulating, the erotically-charged positioning between the white woman and the black man. Much can and has 
been said about all this (e.g. Doane, 1999), as also equally the absence of subject position accorded black women (Bergner,1995).

${ }^{15}$ This includes the complex 'both-and' of being subjected to the universalized and transhistorical black experience, and also divorced from it - as the particularised, exoticised and discretionary exception from the racist rule : "When people like me they tell me it is in spite of my colour. When they dislike me, they point out that it is not because of my colour. Either way I am locked into the infernal circle." (BSWM, p.82-3)

${ }^{16}$ Indeed 'child' fails to appear in the Index of Black Skins, White Masks, nor in Macey's (2012) biography, or Silverman's (2005) collection. (The translations of Fanon's Wretched and A Dying Colonialism do not have Indexes.) Nor does 'child' appear in the many collections that reprint and discuss this iconic encounter (e.g. Evans and Hall, 1999).

${ }^{17}$ Adequate consideration of the significance of the use of the definite article 'the' rather than 'a' in Fanon's description merits another paper, but clearly at the very least its use emphasises the child's importance, i.e. the importance of this, specific, child. The question then arises of whether this could be any child, or has been singled out as an exception rather than prototype.

18 "For the Martinican Fanon, the experience of coming under the white gaze reproduces the primal experience of the island's history: slavery and a colonization so brutal as to be a form of trauma or even annihilation." (Macey, 2012, p.166)

${ }^{19}$ This is not to accord such 'empirical' children privileged ontological status (since all textual representations should be read as equivalent) but rather to reflect Fanon's own depiction. See Lesnik-Oberstein's (2010) critique of the ways even resolutely antihumanist accounts, such as Edelman (2004), fall foul of this error.

${ }^{20}$ Which Macey (2012) attributes to Sartre's Preface rather than Fanon's text in WE.

${ }^{21}$ Earlier cultural studies reception of Fanon's writings tended to overlook his medical/psychiatric/therapy background: c.f. the biographical gloss provided in the influential 1999 Visual Culture reader (p.xi) "He remained in France after the war to study essays and plays and while there wrote his most influential statement of anti-colonial revolutionary thought, Black Skin, White Masks (1952)". His work is, however, also discussed within specifically psychiatric literatures, especially as he also wrote important critiques of French colonial psychiatry and its demeaning depictions of 'native' mental illness (see Keller, 2007; Menozzi, 2015; Murard, 2008; Razanajao, et al. 1996).

${ }^{22}$ However I want to keep some distance from Stockton's (2009) 'child queered by color' which, in my view, takes a worryingly assimilative approach that not only reinstates identity politics but also its prime problem of hierarchies of oppression, by subordinating racism to a general and diluted notion of 'queer'.

23 'Apocalyptic' is Fanon's description of the Swedish journalist's report of a seven year old child who had survived terrible atrocities demanding revenge for the death of his parents he quotes in the Preface to $D C$. 